\title{
Atypical actinobacillosis in bulls in Argentina: granulomatous dermatitis and lymphadenitis ${ }^{1}$
}

\author{
Carlos A. Margineda ${ }^{2}$, Ernesto Odriozola ${ }^{2 *}$, Ana Rita Moreira² ${ }^{2}$ Germán Cantón ${ }^{2}$, Juan \\ Francisco Micheloud ${ }^{2}$, Pedro Gardey², Maximiliano Spetter ${ }^{2}$ and Carlos M. Campero ${ }^{2}$
}

\begin{abstract}
Margineda C.A., Odriozola E., Moreira A.R., Cantón G., Micheloud J.F., Gardey P., Spetter M. \& Campero C.M. 2013. Atypical actinobacillosis in bulls in Argentina: granulomatous dermatitis and lymphadenitis. Pesquisa Veterinária Brasileira 33(1):1-4. Instituto Nacional de Tecnología Agropecuaria (INTA), Estación Experimental Agropecuaria Balcarce, Ruta 226 Km 73,5 (7620) Balcarce, Argentina. E-mail: eodriozola@balcarce.inta.gov.ar

Actinobacillosis is a common cause of sporadic infection in cattle. It was mostly characterized as a pyogranulomatous inflammation of the tongue, but also soft tissues as lymph nodes, other digestive tract localization and skin. The aim of this study was to describe an episode of granulomatous dermatitis and lymphadenitis affecting a bull herd in Argentina during 2010. Actinobacillus lignieresii was isolated from samples collected from one of the affected bulls, and characteristic lesions were observed. Lesions other than 'wooden tongue' are usually uncommon; however, actinobacillosis should be included as a differential diagnosis for cutaneous diseases.
\end{abstract}

INDEX TERMS: Actinobacillosis, dermatitis, lymphadenitis, cattle.

RESUMO.- [Actinobacilose atípica em touros na Argentina: dermatite granulomatosa e linfadenite.] A actinobacilose é causa comum de infecções esporádicas em bovinos. Esta afeção tem sido caracterizada como uma infecção piogranulomatosa não somente da língua como também de tecidos moles tais como linfonodos, ou outras localizações no trato digestivo e na pele. 0 objetivo do presente trabalho é descrever um episódio de dermatite piogranulomatosa e linfadenite que afetou um rebanho de touros na Argentina em 2010. As amostras recolhidas de um dos animais afetados permitiram o isolamento de Actinobacillus lignieresii. Observaram-se as lesões características da doença. Habitualmente não são comuns outras lesões para além das descritas como "língua de pau", no entanto, a actinobacilose deve ser incluída como um possível diagnóstico diferencial de doenças cutâneas.

TERMOS DE INDEXAÇÃO: Actinobacilose, dermatite, linfadenite, bovinos.

\section{INTRODUCTION}

Actinobacillosis is an infectious disease with a worldwide distribution, caused by Actinobacillus lignieresii. It is

\footnotetext{
${ }^{1}$ Received on July 25, 2012.

Accepted for publication on September 18, 2012.

${ }^{2}$ Instituto Nacional de Tecnología Agropecuaria (INTA), Estación Experimental Agropecuaria Balcarce, Ruta $226 \mathrm{Km} \mathrm{73,5} \mathrm{(7620)} \mathrm{Balcarce,} \mathrm{Ar-}$ gentina. ${ }^{*}$ Corresponding author: eodriozola@balcarce.inta.gov.ar
}

a small Gram-negative rod that often affects the soft tissues of cattle and sheep (Swarbrick 1967, Carter 1979, Rycroft \& Garside 2000, Vadillo et al. 2002, Dirksen et al. 2005, Radostits et al. 2007), although it has been found in other species including horses, pigs and humans (Beaver \& Thompson 1933, Carter 1979, Orda \& Wiznitzer 1980). Commensal $A$. lignieresii inhabits the upper digestive tract of ruminants. Later lesions are capable of altering the oral mucosa or skin barrier integrity and can establish an infection (Hebeller et al. 1961, Campbell et al. 1975, Rycroft \& Garside 2000, Radostits et al. 2007). Iatrogenic origin of $A$. lignieresii infections has also been reported (Rebhun et al. 1988, De Kruif et al. 1992).

Grossly, actinobacillosis is characterized by the presence of granulomas with purulent discharges characteristically containing 'sulfur' granules (small, hard yellow to white). Microscopically, pyogranulomas with club-like rosettes with central mass of bacteria surrounded by fibrosis after acute local inflammation are the most common features. In cattle, the classical presentation of infection affects the tongue ("wooden tongue"), but also soft tissues such as lymph nodes (retropharyngeal and submandibular) and other tissues of the head, pharynx, chest, flank, stomach, omentum and limbs can be affected (Abdul Rahman 1980, Aslani et al. 1995, Milne et al. 2001, Dirksen et al. 2005, Radostits et al. 2007, Taghipour Bazargani et al. 2010). Atypical presentations in ruminants have been described 
in the muzzle, nasal cavity, cervical area, lungs, skin and subcutaneous tissues of eyelids and neck (Campbell et al. 1975, Salamanco et al. 1982, Rebhun et al. 1988, Dirksen et al. 2005, Radostits et al. 2007, Angelo et al. 2009, Peli et al. 2009, Magnano et al. 2010, Taghipour Bazargani et al. 2010). Granulomatous lesions caused by A. lignieresii have been also described in dermis following caesarian sections in cattle (De Kruif et al. 1992).

In some herds, lingual actinobacillosis appears in the form of sporadic outbreaks; while in others it has an endemic presentation with $1 \%$ annual prevalence (Dirksen et al. 2005). In Argentina, "wooden tongue" is frequent during the summer affecting mainly young animals (fattening steers and heifers) (Späth et al. 2004). Nevertheless there are also reports of unusual presentations with high prevalence affecting precrural, prescapular, and popliteal lymph nodes, and skin lesions in feedlot cattle (Dirksen et al. 2005, MacInnes 2010).

The aim of this work is to describe the clinical, bacteriological and pathological features observed during a cutaneous actinobacillosis outbreak affecting bulls in Argentina.

\section{MATERIALS AND METHODS}

The outbreak was registered during August 2010 in a commercial farm in Guaminí, Buenos Aires province, Argentina (37오 $62^{\circ} \mathrm{W}$ ). The affected herd consisted of 34, 22-month-old Aberdeen Angus bulls. The animals were grazing an oat pasture (Avena sativa) during the day and stayed overnight in a paddock were they were fed corn (Zea mays) and Italian millet (Setaria italica) hay ad libitum. Two bulls (Bulls A and B) showed skin lesions.

After clinical examination pus was collected by punction of the prescapular lymph node from animal B. This sample was inoculated onto MacConkey Agar plates, and then incubated under aerobic conditions at $37^{\circ} \mathrm{C}$ for $48 \mathrm{hrs}$. Same samples were also cultured in Columbia Blood-Agar plates in an anaerobic jar $110 \%$ $\mathrm{CO}_{2}$ ) at $37^{\circ} \mathrm{C}$. Colonies were identified by conventional biochemical tests and Gram staining. Kirby-Bauer antibiotic test was carried out using individual antimicrobial disc on Müller-Hinton agar. Animal A had been previously treated with oxitetracycline; and for this reason samples were not collected for bacterial culture

After local anesthetic application, full thickness incision biopsies of the skin were taken from animal B and fixed in 10\% formalin for histopathological analysis. After fixation the tissues were processed by standard procedures for the production of Hematoxylin and eosin and Gram stained sections.

\section{RESULTS}

During clinical inspection lameness and proliferative skin lesions involving different areas of the body were observed. According to the farmer, Bull A had showed lesions from 40 days ago. These were characterized by subcutaneous pliable nodular formations of $\sim 15 \mathrm{~cm}$ diameter in the inguinal area, on lateral to the scrotum base. Oxitetracycline treatment was given 20 and 3 days before inspection. After punction, hemorrhage and a thick yellowish discharge was observed. The farmer reported that the lesions in Bull B were present 30 days prior examination. Multifocal single to coalescing subcutaneous tractable nodular formations
( 5 to $15 \mathrm{~cm}$ in diameter) were evident in the lateral surface of the left hind limb. The skin of this area was alopecic and some of the nodules were ulcerated with crusts and multiple fistulas draining a thick purulent material. These nodular formations were also appreciated in muscles of the area, and on the lateral, caudal and medial subcutaneous areas of the same hind limb (Fig.1 and 2). Enlargement of the left popliteal lymph node was also noted. Less severe and non-fistulated lesions were found in skin of the right hind limb, flank and rib cage. The right prescapular lymph node was also enlarged $(15 \mathrm{~cm}$ in diameter); upon punction of the lymph node, a foul smelling purulent exudate was drained. The rectal temperature of this animal was within reference ranges.

Actinobacillus lignieresii was isolated from the exudate collected from Bull B. This isolate was resistant to amikacin, amoxicillin-clavulamic acid, cefotaxime, cephalexin, erythromycin, neomycin, cloxacillin, rifampicin, vancomycin, ampicillin, enrofloxacin and penicillin, and was sensitive to tilmicosin, tetracycline, oxitetracycline, streptomycin, cefaclor, cefalotin, cloranfenicol, florfenicol, gentamicin, kanamycin, norfloxacin, ofloxacin, sulfonamides, trimeto-

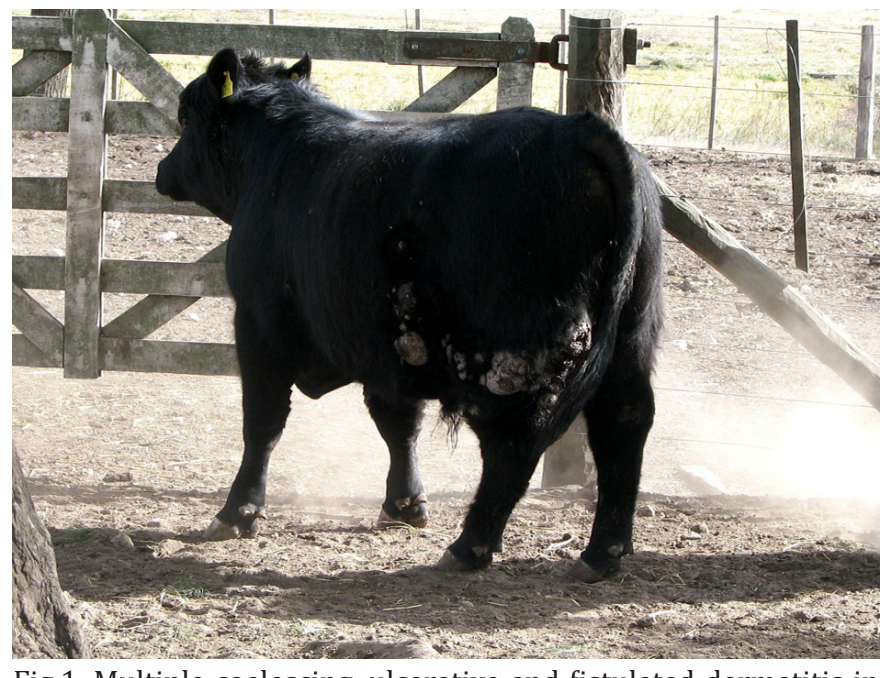

Fig.1. Multiple coalescing, ulcerative and fistulated dermatitis in the left hind limb of Bull B.

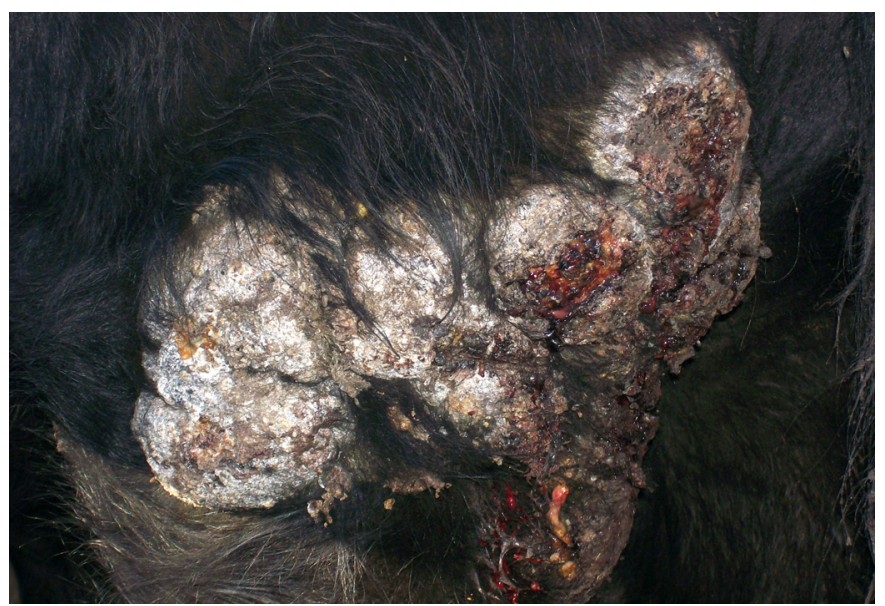

Fig.2. Higher magnification of the lesion in the left hind limb of Bull B. 
prim/sulfametoxazol, nalidixic acid, doxycycline, fosfomycin and polymyxin B.

Histologically, the biopsy collected from Bull B showed pyogranulomatous dermatitis with generalized and diffuse interstitial macrophage, epithelioid cell and neutrophils infiltration. Severe fibroplasia and multiple pyogranulomas surrounding eosinophilic club-like rosettes (Splendore-Hoeppli phenomenon) with Gram negative coccobacilli colonies were observed (Fig.3). In the epidermis, the number of hair follicles was reduced and proteinaceous material deposit was observed, with degenerated neutrophils and multiple rosettes with Gram negative bacteria.

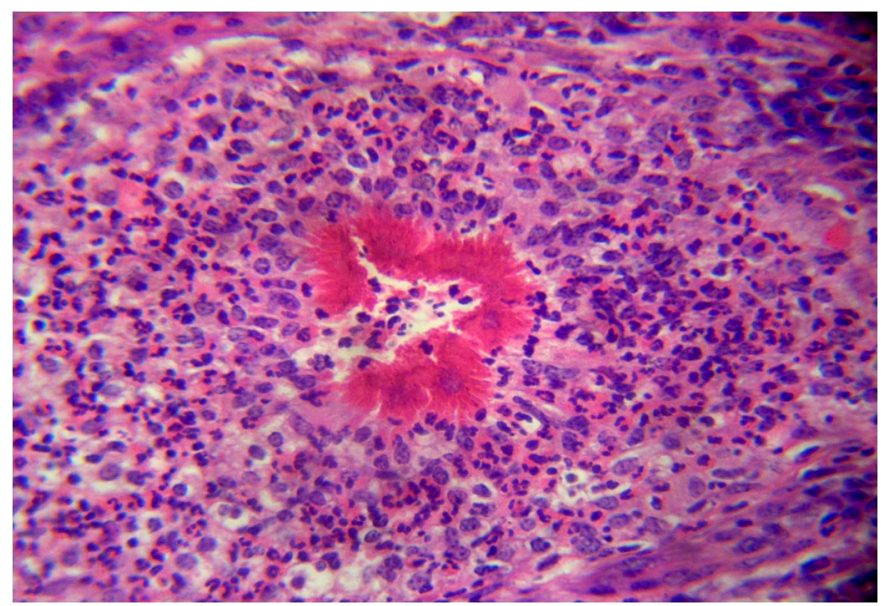

Fig.3. Pyogranulomatous dermatitis with neutrophils surrounding eosinophilic club-like rosettes (Splendore-Hoeppli phenomenon). HE, 400×.

\section{DISCUSSION}

Actinobacillosis is a frequently diagnosed disease of ruminants and glossal presentation is the most common feature, leading to starvation due to difficulty for the prehension and swallowing processes. Lymphadenitis and granulomatous inflammation affecting other tissues have been also reported (Rebhun et al. 1988, Anderson et al. 1990, Milne et al. 2001, Radostits et al. 2007). In the current report, granulomatous dermatitis and enlargement of several lymph nodes were observed in the affected animals. The clinical presentation, characteristic of the lesions and the isolation of Actinobacillus lignieresii from the affected tissues in one of the affected bulls (Bull B) confirmed the diagnosis of actinobacillosis.

This clinical presentation was previously reported in cattle including large skin granulomas of several centimeters in diameter and associated lymph nodes (Hebeller et al. 1961, Anderson et al. 1990, Aslani et al. 1995, Milne et al. 2001, Radostits et al. 2007, Taghipour Bazargani et al. 2010). Similar to the lesions described in this case, the previously described granulomas were usually pliable on palpation, and bleed easily and non-odorous caseous to purulent material was obstained when they were drained (Rycroft \& Garside 2000, Radostits et al. 2007).

Definitive diagnosis was confirmed after culture of the organism from the lesion. However, identification of A. lignieresii from chronic lesions is usually complicated, espe- cially after antibiotic therapy (Fubini \& Campbell 1983). Sensitivity test confirmed that the A. lignieresii isolated from animal B was streptomycin and sulfonamide-sensitive, antibiotics usually used to treat these cases (Campbell et al. 1975, Radostits et al. 2007). Penicillin is also indicated for the treatment for actinobacillosis (Radostits et al. 2007); however the isolate in this outbreak resulted penicillin-resistant, which has been reported before (Milne et al. 2001). Other antibiotics identified as effective in controlling the growth of this particulate isolate could contribute with useful information about Actinobacillus treatment in other cases in different species. Infection by $A$. lignieresii can also have zoonotic implications, since human actinobacillosis has been identified following bite produced by horses (Benaoudia et al. 1994).

Due to the difficulties in the bacteriological diagnosis, histopathological examination of biopsies is usually helpful for the diagnosis of actinobacillosis (Milne et al. 2001). The histopathological changes observed in the skin biopsy from the affected bull, were similar to the described in previous reports. Lesions of actinobacillosis have a very distinctive pattern, reported as Actinobacillus granulomas, which consist of neutrophils and club-like rosettes with a central mass of Gram negative bacilli (Splendore hoepli) surrounded by neutrophils, mononuclear cells and fibrosis (Anderson et al. 1990, Aslani et al. 1995, Rycroft \& Garside 2000, Milne et al. 2001, Radostits et al. 2007, Hussein 2008, Angelo et al. 2009, Taghipour Bazargani et al. 2010).

A. lignieresii tissue invasion most commonly starts penetrating lesions or lacerations produced by abrasive materials in the environment (Radostits et al. 2007). In this case, the infection was probably introduced through lacerations produced during fights between the bulls in the paddocks where the bulls stayed overnight.

These cases of cutaneous and lymph node lesions due to A. lignieresii infections are rare and to date have not been reported in Argentina. In this case the affected animals showed a favorable response after skin lesion removal surgery, lymph node drainage and treatment with appropriate antibiotics.

\section{CONCLUSION}

Lesions caused by Actinobacillus lignieresii other than 'wooden tongue' are uncommon and consequently many practitioners may not be familiar with them. The description of this atypical case stresses the importance to include Actinobacillosis as a differential diagnosis for proliferative cutaneous lesions in cattle.

Acknowledgements.- We thank Lilian Lischinsky and Rosana Malena for carrying out complementary laboratory techniques at INTA EEA Balcarce and Gustavo Sánchez for the invaluable anamnestic information provided in relation to the field case.

\section{REFERENCES}

Abdul Rahman S.O. 1980. Actinobacillosis of the omentum in a cow. Pertanika 3:64-65.

Anderson K.L., Fairley R.A. \& Duncan D. 1990. Suspected actinobacillosis manifested by facial enlargement in a heifer. J. Am. Vet. Med. Assoc. 197:1359-1360. 
Angelo P., Alessandro S., Noemi R., Giuliano B., Filippo S. \& Marco P. 2009. An atypical case of respiratory actinobacillosis in a cow. J. Vet. Sci. 10:265-267.

Aslani M.R., Khodakaram A. \& Rezakhani A. 1995. An atypical case of actinobacillosis in a cow. J. Vet. Med. 42:485-488.

Beaver D.C. \& Thompson L. 1933. Actinobacillosis of man: report of a fatal case. Am. J. Pathol. 9:603-622.

Benaoudia F., Escande F. \& Simonet M. 1994. Infection due to Actinobacillus lignieresii after a horse bite. Eur. J. Clin. Microbiol. Infect. Dis. 13:439-440.

Campbell S.G., Whitlock T.R.H., Timoney J.F. \& Underwood A.M. 1975. An unusual epizootic of actinobacillosis in dairy heifers. J. Am. Vet. Med. Assoc. 166:604-606.

Carter G.R. 1979. Diagnostic Procedures in Veterinary Bacteriology and Mycology. $3^{\text {rd }}$ ed. C.E. Thomas Publisher, USA. 108p.

De Kruif A., Mijten P., Haesebrouck F., Hoorens J. \& Devriese L. 1992. Actinobacillosis in bovine caesarean sections. Vet. Rec. 131:414-415.

Dirksen G., Gründer H.D. \& Stöber M. 2005. Medicina Interna y Cirurgía del Bovino. Vol.1. 4⿳亠丷a ed. Interamericana, Buenos Aires, p.131-132.

Fubini S.L. \& Campbell S.G. 1983. External lumps on sheep and goats. Vet. Clin. North Am., Large Anim. Pract. 5:457-476.

Hebeller H.F., Linton A.H. \& Osborn A.D. 1961. Atypical actinobacillosis in dairy herd. Vet. Rec. 73:517-521.

Hussein M.R. 2008. Mucocutaneous Splendore-Hoeppli phenomenon. J. Cutan. Pathol. 38:979-988.

MacInnes J.I. 2010. Actinobacillus, p.363-386. In: Gyles C., Prescott J., Songer G. \& Thoen C. (Eds), Pathogenesis of Bacterial Infections in Animals. $4^{\text {th }}$ ed. Blackwell, Iowa.

Magnano G.G., Macias A.F., Mació M.N., Costamagna F., Caminos J.M., Sticotti E., Scheneider M.O., Schleef N. \& Giraudo J.A. 2010. Actinobacilosis atípica en un engorde de bovinos. VII Reunión Argentina de Patología Veterinaria (Rapave), Buenos Aires.

Milne M.H., Barrett D.C., Mellor D.J., Fitzpatrick J.L. \& O’Neill R. 2001. Clinical recognition and treatment of bovine cutaneous actinobacillosis. Vet. Rec. 148:273-274.

Orda R. \& Wiznitzer T. 1980. Actinobacillus lignieresii human infection. J. Royal Soc. Med. 73:295-297.

Peli A., Spadari A., Romagnoli N., Bettini G., Scarpa F. \& Pietra M. 2009. An atypical case of respiratory actinobacillosis in a cow. J. Vet. Sci. 10:265267.

Radostits O.M., Gay C.C., Hinchcliff K.W. \& Constable P.D. 2007. Veterinary Medicine. A Textbook of the Diseases of Cattle, Horses, Sheep, Pigs, and Goats. Saunders Elsevier, Spain.

Rebhun W.C., King J.M. \& Hillman R.B. 1988. Atypical actinobacillosis granulomas in cattle. Cornell Vet. 78:125-130.

Rycroft A.N. \& Garside L.H. 2000. Actinobacillus species and their role in animal disease. Vet. J. 159:18-36.

Salamanco A., Odeón A. \& Moreira A.R. 1982. Epizootias inusuales de actinobacilosis. Gaceta Veterinaria 44:367.

Späth E., Entrocasso C., Plorutti F., Brusca G., Manazza J., Quirós J. \& Maresca S. 2004. Principales enfermedades en bovinos de cría en la Cuenca del Salado en los años 2001 al 2003 y su impacto en la producción. Jornadas de Perfeccionamiento de Interacción Profesional, Ayacucho y Azul, Argentina.

Swarbrick 0. 1967. Atypical actinobacillosis in three cows. Brit. Vet. J. 123:70-75.

Taghipour Bazargani T., Khodakaram Tafti A., Atyabi N. \& Faghanizadeh G. 2010. An unusual occurrence of Actinobacillosis in heifers and cows in a dairy herd in Tehran suburb-Iran. Arch. Razi Institute 65:105-110.

Vadillo S., Píriz S. \& Mateos E. 2002. Manual de Microbiología Veterinaria. McGraw-Hill-Interamericana, Madrid, p.357-364. 